\title{
THE EFFECTS OF ENCLOSING CULTIVATED LAND ON THE PHYSICAL PROPERTIES OF SOIL IN THE LOESS HILL REGION OF ORDOS
}

\author{
Lin WANG *, Fengna XUE *, Wenbang GAO *, Jing SHI *, Shanshan SUN *, \\ Junxiu LIU *, Rina SU *, Yunhu XIE *, Chunxing HAI * and Li XIAOJIA ** \\ * Inner Mongolia Normal University, College of Geographical Science, Zhaowuda Road 81, Saihan \\ District, Hohhot, China, linwang2012@126.com, 642852289@qq.com, 305349946@qq.com, \\ 1169945298@qq.com, 632446928@qq.com, 919259749@qq.com, 495006332@qq.com, \\ ** Inner Mongolia Normal University, College of Geographical Science, Zhaowuda Road 81, Saihan
} xieyhsd@163.com, hcxjs@imnu.edu.cn District, Hohhot, China, lixiaojia1981128@163.com

DOI: 10.1515/trser-2015-0090

KEYWORDS: Soil bulk density, porosity and moisture, Ordos Region, China.

\section{ABSTRACT}

Protection of the environment by returning farmland to forest and grassland through enclosing areas of land to permit regeneration of native flora is being implemented in the Loess hill region of China. Soil physical properties are important components of ecological systems, as comparisons between cultivated and enclosed areas demonstrate. The results showed: the soil moisture content in the enclosed area was $14.6 \%$ and that in the cultivated area was 14\%; the soil bulk density and soil porosity were respectively $1.45 \mathrm{~g} / \mathrm{cm}^{3}$ and $45.28 \%$ in the enclosed areas, and respectively $1.46 \mathrm{~g} / \mathrm{cm}^{3}$ and $44.79 \%$ in cultivated land. The alteration of soil physical properties was not big between cultivated areas and enclosed areas in the short term.

ZUSAMMENFASSUNG: Die Auswirkungen umfriedeter Nutzflächen auf die physikalischen Eigenschaften des Bodens im Loesshügelgebiet von Ordos.

Der Schutz der Umwelt durch Rückführung von Ackerland zu Wald und Grünland durch Einbeziehung von Landflächen, die Regenerierung der einheimischen Flora ermöglichen wurde in der Loesshügel Region von China umgesetzt. Die physikalischen Eigenschaften des Bodens sind wichtige Bestandteile der Ökosysteme, wie es der Vergleich zwischen bebautem und dem eingefriedeten Feld belegt. Die Ergebnisse zeigen, dass die Bodenfeuchtigkeit im eingefriedeten Bereich $14,6 \%$ und der im freien angebauten $14 \%$ betrug. Die hohe Bodendichte und Bodendurchlässigkeit zeigte jeweils $1,45 \mathrm{~g} / \mathrm{cm}^{3}$ und $45,28 \%$ im abgeschlossenen Bereich sowie $1,46 \mathrm{~g} / \mathrm{cm}^{3}$ and $44,79 \%$ im offenen bebauten Land. Die Veränderung der physikalischen Eigenschaften des Bodens wies im kurzfristigen Vergleich der beiden Flächen keine großen Unterschiede auf.

REZUMAT: Efectele împrejmuirii terenurilor cultivate asupra proprietăților fizice ale solului în podișul de loess al Ordosului.

În podișul loessoid al Ordosului în China mediul este protejat prin redarea terenurilor agricole utilizării în regim forestier și păşunatului prin împrejmuirea parcelelor de teren pentru a permite regenerarea florei native. Proprietățile fizice ale solului sunt componente importante ale sistemelor ecologice, așa cum o demonstrează comparația dintre parcelele cultivate și cele necultivate. Rezultatele au arătat următoarele: umiditatea din sol în parcela împrejmuită a fost de 14,6\% iar cea din zona cultivată a fost de $14 \%$; densitatea brută a solului și porozitatea au fost de $1,45 \mathrm{~g} / \mathrm{cm}^{3}$ și $45,28 \%$ în parcelele împrejmuite, respectiv de $1,46 \mathrm{~g} / \mathrm{cm}^{3}$ și respectiv 44,79\% în cele cultivate. Pe termen scurt, proprietățile fizice ale solului nu au variat semnificativ de la parcelele cultivate la cele împrejmuite. 


\section{INTRODUCTION}

The loess hills are the main landforms of the Loess Plateau in China, accounting for $48 \%$ of the total area of the Loess Plateau. The Loess Plateau is the largest loess deposition area in the world, with low precipitation, sparse vegetation and serious soil erosion (Yan et al., 2014). The loess hills are one of the main soil erosion areas in China: the terrain is fragile, the soil is loose and the vegetation and ecosystem are severely damaged. This situation is the result of an intertwined combination of ecological degradation and poverty, and the region is the focus of national ecological re-construction. In recent decades vegetation restoration has improved and soil erosion has been gradually contained through the implementation of a series of major ecological projects by national and local governments, including projects on returning farmland to forest and grassland, a natural forest protection project, and key soil and water conservation projects. This paper reports on one of these projects, the project of returning farmland to forest and grassland, the ultimate goal of which is to stop agricultural production and associated serious soil and water loss on the slopes of the upper reaches of the Yangtze River and the middle and upper reaches of the Yellow River and to encourage the restoration of forest and grassland to improve the ecological environment in the western region, the adjustment of economic and the sustainable development of the whole society (Yuan, 2006).

Returning farmland to forest and grassland is a basic measure to control soil and water loss on the Loess Plateau. The change in the underlying surface conditions will inevitably lead to change of soil physical properties and thus affect the regional material migration and transformation. Soil physical properties are one of the important physical characteristics of soil and are an important part of ecological benefits. Soil is a natural body, which is non-uniform and continuously changing. Soil properties are affected by internal factors (including parent material and soil formation processes, etc.) and external factors (including land management methods, fertilization, rotation, etc.). The physical properties of soil are affected by factors such as geomorphological factors, vegetation coverage, vegetation types and tillage degree under the combined influence of natural conditions and human factors.

The result of soil modification is important for the realistic use and conservation of regional soil and water resources. Returning farmland to forest improves the ecological environment by improving soil physical properties through the vegetation litter layer, thereby changing the surface characteristics of the root system, and affecting the abundance and composition of surface organism species (Xiang-hua et al., 2005).

Soil is the main limiting factor for vegetation here, due to the nature of loess deposits, which have poor soil water retention capacity, low soil nutrient content, and are eroded (Zhang et al., 2009). Soil bulk density is considered to be a useful parameter of soil structure (Hernanz et al., 2000). It is related to other soil properties, such as soil porosity, soil water content and hydraulic conductivity, as an important indicator to measure the quality of soil (Dam et al., 2005). The soil bulk density is an important index of soil tillage quality and fertility (Huang Changyong, 2000). The soil bulk density is the basic physical properties of the soil, and refers to the quality and weight of unit volume body (including soil particles and voids) in the natural state (Walker 1993; Zheng et al., 2004), which has an important influence on soil permeability, infiltration capacity, water holding capacity, solute transport and soil anti erosion ability (Zheng et al., 2004). Under natural conditions, the soil bulk density is a soil property with high degree of variability due to the influence of the soil-forming parent material, soil forming process, climate, and biological effects (Qiu et al., 2015). It is not only an important supplementary standard to measure the quality of soil fertility (Wang, 1996), but also an important indicator to evaluate the soil erosion resistance of sloping land (Wilson et al., 2005), which is of great significance in this study of returning farmland to forest and grassland. 
The soil physical properties of farmland that has been returned to grassland/forest in Jixian County of Shanxi Province were studied based on the ring sampler method. Returning farmland to forest had great influence on various soil physical properties, which could lead to the evolution of degraded farmland soil to forest soil in a short time. The soil structure improved with time: total porosity increased, soil water and heat coordination increased, soil water holding capacity increased, the nutritional richness and supply of water was strengthened which is important for water preservation, and soil and water conservation, and soil corrosion resistance were enhanced significantly.

The modifications in the physical properties of soil in diverse croplands transformed to forest land were researched by Xing Juxiang in Wuqi County. The results showed that soil non-capillary porosity varied significantly according to different types of land use after returning farmland to forest, but that soil depth had no significant effect on soil porosity. No matter what type of land conversion, soil clay content in reforestation regions was higher than those in arable lands. Soil clay content did not increase significantly at depths between $0-20$ $\mathrm{cm}$, but was largely increased at depths of 20-40 cm and 40-60 cm. Soil was improved significantly in $0-20 \mathrm{~cm}$ soil layer and the soil bulk density in the $0-20 \mathrm{~cm}$ soil layer was significantly lower than that in the $20-40 \mathrm{~cm}$ soil layer and $40-60 \mathrm{~cm}$ soil layer. (Xing et al., 2010)

Grassland degradation results in the increase of soil bulk density and the decrease of water content in soil (Zhou et al., 2005; Zhao et al., 2010), it alters the coarseness of surface soil particles and leads to deterioration of soil structure (Liu et al., 2009).

In this paper, soil moisture content, soil bulk density and soil porosity were compared and analyzed in enclosing region and cultivated region in loess hilly region. It could provide scientific reference for the implementation of ecological environment protection in hilly areas.

\section{MATERIAL AND METHODS}

\section{Study area}

The Huangpu River is a tributary of the middle Yellow River, located at latitude $39.2^{\circ}-39.9^{\circ} \mathrm{N}$, longitude $110.3^{\circ}-111.2^{\circ} \mathrm{E}$ with an elevation of $1,482 \mathrm{~m}$ a.s.l. at the highest point and $833 \mathrm{~m}$ elevation at its estuary elevation, a total height difference of $649 \mathrm{~m}$. The Huangpu River originates in the transitional zone of the Ordos Plateau and the Loess Plateau, mainly flows through Zhungeer Banner in Inner Mongolia Autonomous Region and Fugu County in Shaanxi Province, and flows to the Yellow River in Fugu County. It belongs to the continental monsoon climate in the basin. The annual precipitation is 309.5-414.9 mm, precipitation is concentrated in July-September, which accounts for more than $70 \%$ of the annual rain fall, and more in the form of heavy rain. The area is prone to drought and is windy in winter and spring, with an average of 28.5 windy days, up to a maximum of 50 windy days per year. The average wind speed is $19 \mathrm{~ms}^{-1}$, the maximum wind speed $24 \mathrm{~ms}^{-1}$. The annual average temperature of the whole basin is $6.2-7.2^{\circ} \mathrm{C}$, the average temperature in January is $12^{\circ} \mathrm{C}$, the average temperature in July is $23^{\circ} \mathrm{C}$, the extreme minimum temperature is $-32.8^{\circ} \mathrm{C}$ and the extreme maximum temperature is $39.1^{\circ} \mathrm{C}$. 
The study area was located in farmland near Gezhen Village, located in Xuejiawan locality, Zhungeer Banner, Erdos City, Inner Mongolia Autonomous Region. The longitude is $111^{\circ} 8.6^{\prime} \mathrm{E}$ and latitude is $39^{\circ} 45.4^{\prime} \mathrm{N}$. The study area is located in a small watershed of the Ten-Miles-Long River, which is a tributary of the Huangpu River, near the soil and water conservation test station in Hejiawan Village of Zhungeer Banner. It is sparsely populated near the study area, inhabited by only a few farmers. Traditional farming methods are widespread and affected by the local terrain conditions, by the temperature, precipitation and other meteorological factors. Typically, one crop per year is taken, and the most common crops are corn, sorghum and potato. Sowing time is generally in mid-April each year, and harvest in late September. The surface remains bare in the rest of time.

The enclosing plots selected in this paper began to be enclosed in 2011. They belonged to natural returning farmland, and the enclosure time was three years. Soil samples were extracted in 2014. In this paper, the enclosed area is compared with soil samples taken from farmland areas which have not been enclosed or cultivated in order to investigate whether the soil physical properties may be improved after the enclosure. A control observation plot was selected to illustrate the problem.

Field survey was conducted in March, 2014, and the enclosed and cultivated study areas were selected. Soil samples were collected in the study areas under the sunny weather in order to minimize the impact of external conditions on soil indicators, which would be tested. The research area selected in this paper is located in Erdos City, Inner Mongolia Autonomous Region (Fig. 1a). The enclosed area (Fig. 1b) was selected as the study area in the loess hilly region, and 15 sampling sites were evenly distributed in the enclosed area (Fig. 1c). The samples are diagonally distributed. The selected cultivated area is located on the right side of the enclosed area. Considering the conditions of the area, slope degree and slope position of the cultivated area and the enclosed area, the soil physical properties of the two studied areas should be studied under the same external conditions. The sampling method is the same as that of the enclosed area, and the sampling unit is distributed in a contrasting manner.

Determination of soil moisture content

Soil moisture content was determined by weighing samples before and after drying. In this paper, the determination of soil moisture is the natural soil moisture content. After collection, samples from the soil profile were backed into pre-numbered and weighed (analysis accurately to 0.0001 ) aluminium boxes. These boxes were then weighed (analysis accuracy to $0.0001 \mathrm{~g}$ ) indoors to achieve the wet weight. Soil samples were then oven dried for six-eight $\mathrm{h}$ at $105-110^{\circ} \mathrm{C}$, then the weight of dried soil was determined. The soil moisture was then calculated.

Soil bulk density and soil porosity

The soil bulk density was measured by the ring method. The soil samples were taken in the field by ring method. These samples were dried to a constant weight under the condition of $105^{\circ} \mathrm{C}$ for six-eight h. The weight after cooling and drying by the dryer (weighing balance accuracy is 0.0001 ) was determined. The data was used to calculate the soil bulk density. Soil porosity is not measured directly, but is calculated by specific gravity and bulk density. 


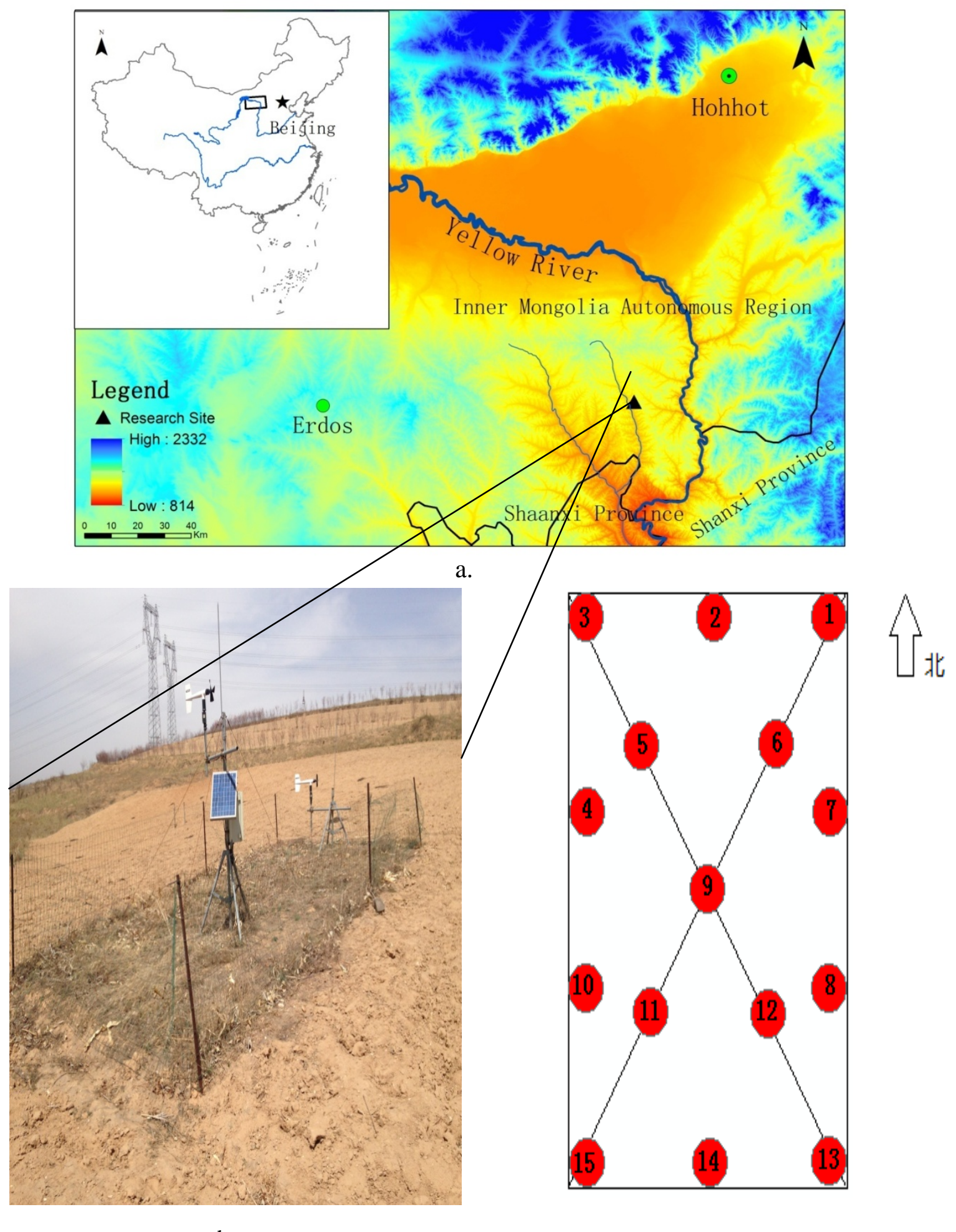

b.

c.

Figure 1a, b, c: Study area and sampling site layout. 
RESULTS AND DISCUSSION

Distribution characteristics of surface soil moisture in enclosed and cultivated areas

Soil water is an important part of the soil and plays an important role in the process of soil formation. The migration of various substances is mainly in the form of solution in the soil layers of the soil profile. Soil water is also involved in a great deal of material transformation in the soil. In addition, soil water is a major source of crop water uptake and is an important link in the natural water cycle. Environmental changes, human damage and other external factors will have great impact on soil moisture content. Soil moisture is the main limiting factor to vegetation restoration and reconstruction in the Loess Plateau, and is also an important factor to determine soil productivity (Fu Bojie et al., 1999). Surface water is mainly derived from precipitation in loess hilly areas, which is absorbed by vegetation through runoff or infiltration in the surface.

Distribution characteristics of surface soil moisture in the enclosed areas

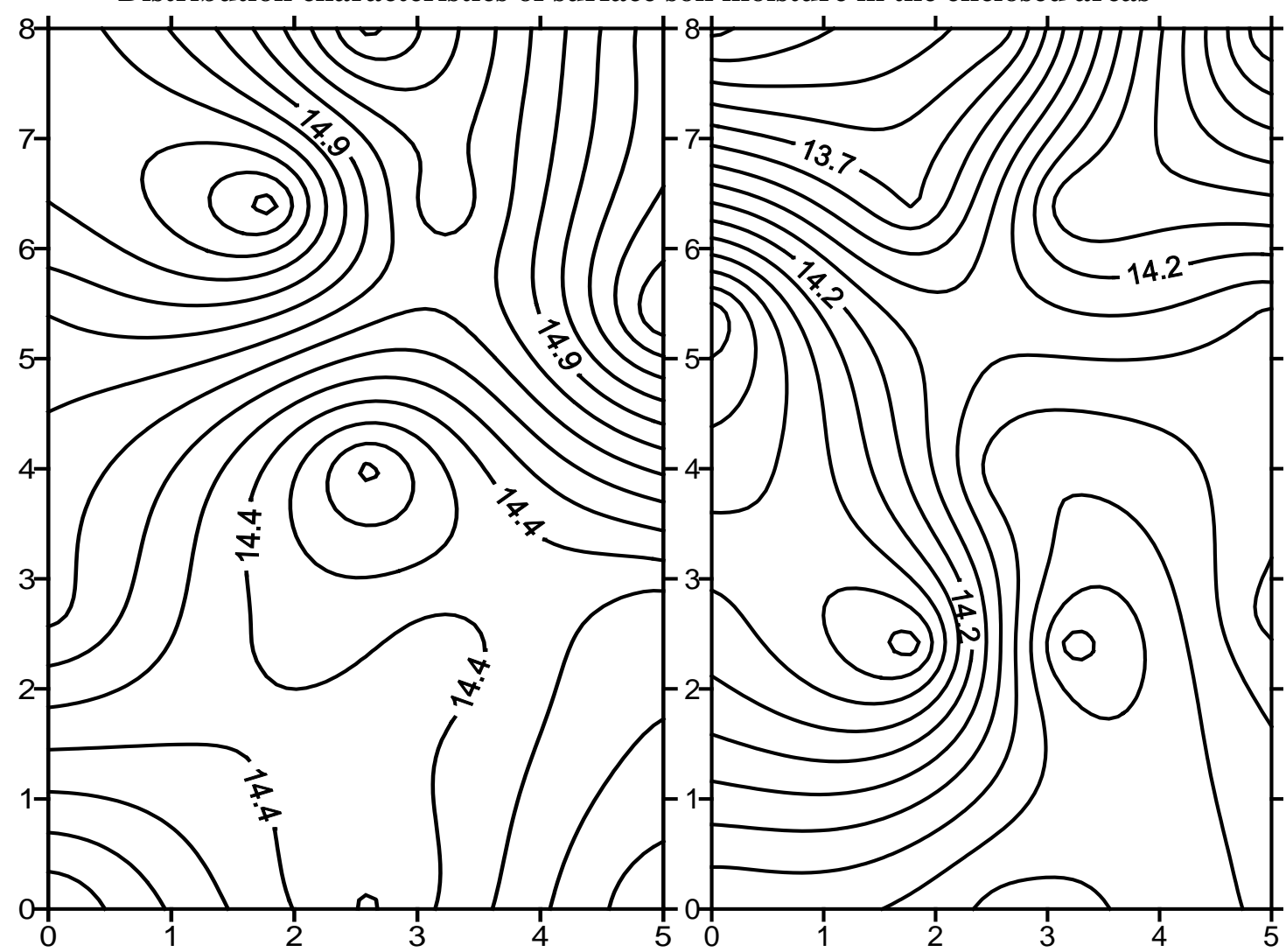

Soil moisture content in enclosure region Soil moisture content in arable region

Figure 2: Soil moisture content in enclosed and cultivated areas.

The soil moisture content in the enclosed area decreased from the north to the south, and the soil moisture content in the southern region was the lowest (14\%). The maximum soil moisture content was $15.4 \%$ in the middle and upper regions, and the average soil moisture content in the enclosed area is $14.6 \%$ (Fig. 2). 
In the enclosed area, the height, density and coverage of the grass layer decreased obviously in the southern area. However, with the reduction of vegetation coverage in the ground surface, soil water evaporation increased and soil water holding capacity decreased, so overall the soil moisture content decreased. Soil moisture content also varies due to the influence of slope degree, which lead to different runoff velocities and runoff amounts after rainfall, and different rates of infiltration (Han Rui-lian et al., 2003; Yang et al., 2012). In addition, from the aspect of slope degree in the enclosed area, the elevation in the northern region is higher than that in the southern region, so the surface runoff flows from the north to the south. The infiltration rate in the south is faster than that in the north, and surface water evaporation is also faster in the south. Soil moisture is thus mainly concentrated in the surface in the northern region, so soil moisture content in the northern region is generally higher than that in the southern region. Because the selected study area is relatively small, the influence of wind direction as a factor is negligible. The purpose of this analysis is to provide a scientific basis for improving soil ecological environment and improving soil quality.

\section{Distribution characteristics of surface soil moisture in cultivated areas}

The change of soil moisture is relatively flat on the vertical profile in farmland under the continuous drought condition because of its lower consumption of deep soil moisture. Therefore, the surface soil moisture content in the cultivated area was studied in this paper. The high value area appeared in the north (Fig. 2). The maximum soil moisture content was $14.9 \%$, the minimum moisture content was $13.3 \%$ and the average value was $14 \%$. Because corn was perennially planted in the cultivated areas and the natural condition and the growth and development characteristics of corn are the same, the effect of field management can be ignored. There was no obvious change in the soil moisture content in cultivated land. The reason may be that the soil condition of cultivated land was the same, and there was not much difference between soil surface water absorption and evaporation. The soil moisture in the loess hill area mainly comes from rainfall runoff and interflow, but in some areas the soil moisture content was high: a possible reason may be due to the loose soil in the cultivated areas after rainfall. The surface water infiltration rate is also important, due to the slow infiltration speed of surface moisture focused on the soil surface, leading to high moisture content in the cultivated areas.

Distribution characteristics of surface soil bulk density and soil porosity in enclosed and cultivated areas

Soil moisture content and bulk density are two important indices of soil physical properties, which have important effects on soil nutrient availability and productivity. The bulk density of soil can be used as one of the indicators of soil maturity. It is shown that the higher the degree of soil matures, the lower the degree of soil bulk density. The soil bulk density is usually $1.00-1.50 \mathrm{~g} / \mathrm{cm}^{3}$. The surface soil bulk density is $1.25-1.35 \mathrm{~g} / \mathrm{cm}^{3}$ after natural deposition and compaction. The soil bulk density of natural soil is lower than that of tilled soil. According to the literature, the soil bulk density of cultivated land, forest and grassland is $0.80-1.60 \mathrm{~g} / \mathrm{cm}^{3}$, and it is only in original Pinus koraiensis forest that the soil bulk density is $0.47 \mathrm{~g} / \mathrm{cm}^{3}$ in the $0-10 \mathrm{~cm}$ layer (Man et al., 1997). Under certain conditions, the soil bulk density will change greatly. For example, the surface soil bulk density in newly cultivated farmland and in paddy fields can be reduced to less than $1.00 \mathrm{~g} / \mathrm{cm}^{3}$ (Guo Ying-jie et al., 1999), because of water flow and natural compaction. The bulk density of compacted soil and sandy soil can increase to $1.40-1.60 \mathrm{~g} / \mathrm{cm}^{3}$ (Feng et al., 2005; Wu et al., 2005). 


\section{Enclosed areas}

Distribution Characteristics of Soil Bulk Density and Soil Porosity in the

Table 1: Relation of soil bulk density, soil porosity and soil compactness; note: this information is from the Agricultural Division Report in Chunhua County.

\begin{tabular}{|c|c|c|}
\hline Soil bulk density $\left(\mathrm{g} / \mathrm{cm}^{3}\right)$ & Soil porosity $(\%)$ & Soil compactness \\
\hline$<1.00$ & $>60$ & Very loose \\
$1.00 \sim 1.14$ & $60 \sim 56$ & Loose \\
$1.14 \sim 1.26$ & $56 \sim 52$ & Suitable \\
$1.26 \sim 1.30$ & $52 \sim 50$ & Less compact \\
$1.30 \sim 1.45$ & $50 \sim 45$ & Compact \\
$>1.45$ & $<45$ & Very compact \\
\hline
\end{tabular}

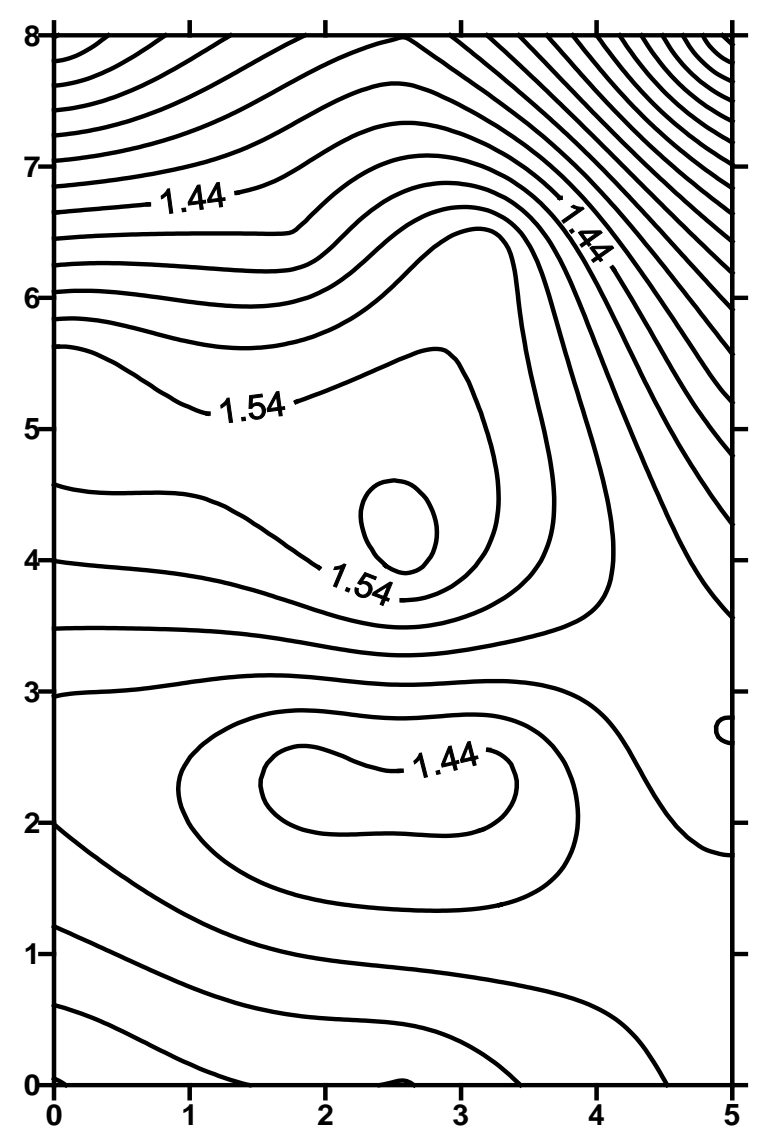

Soil bulk density in the enclosed areas

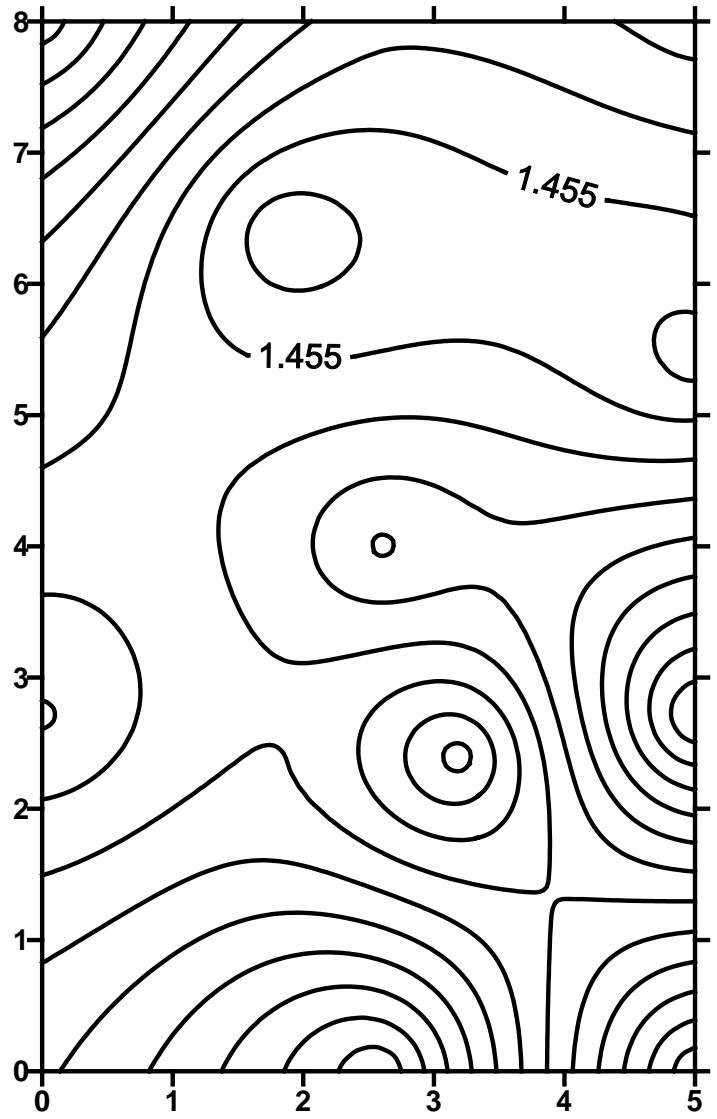

Soil bulk density in the cultivated areas 


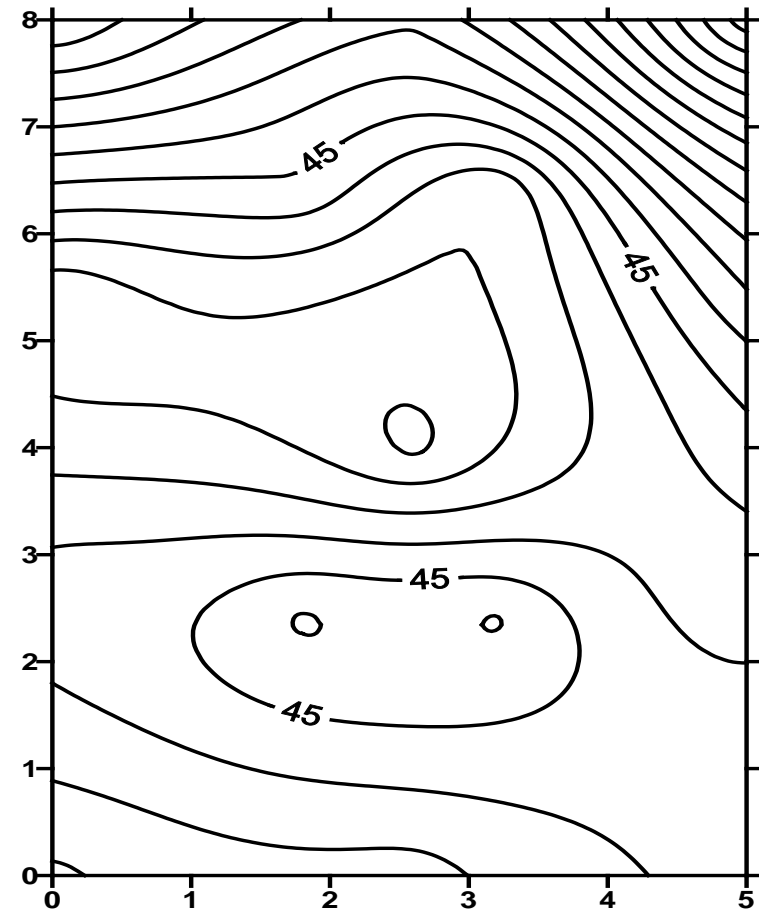

Soil porosity in the enclosed areas

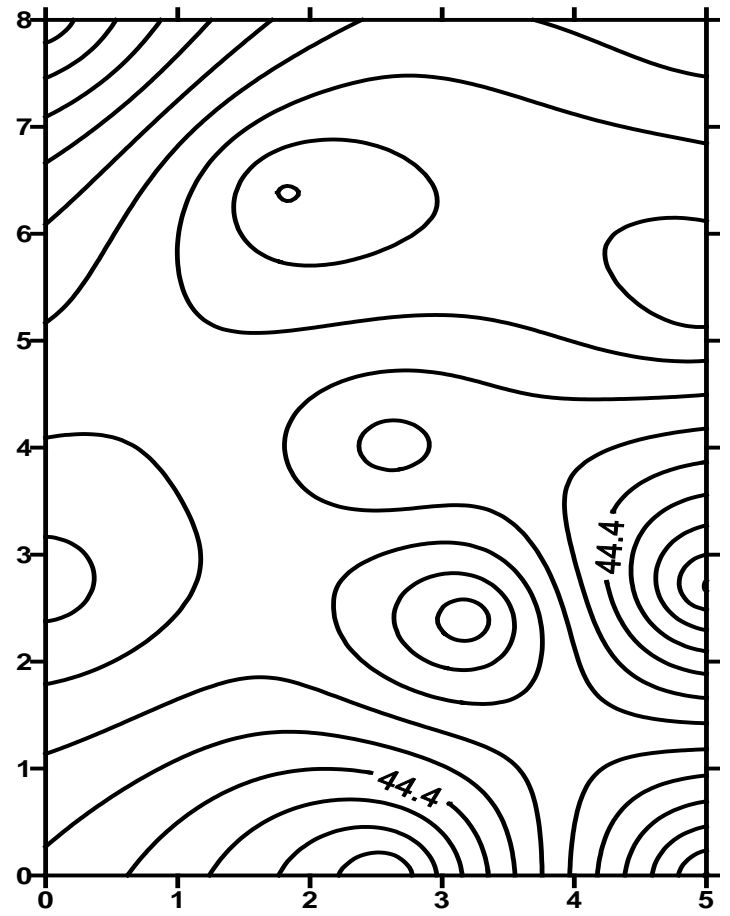

Soil porosity in the cultivated areas

b.

Figure 3a, b: Soil bulk density and soil porosity in the enclosed and cultivated areas.

Soil bulk density reflects the level of soil structure, permeability and water retention capacity. The bulk density is generally greater with increased soil depth. Low soil bulk density illustrates good soil structure and permeability, and high fertility. In constrast, high soil bulk density indicates soil compaction, poor structure and low permeability. Porosity reflects the soil pore condition and tightness. Soil porosity of coarse sand is generally 33-35\% with larger pores. The porosity of clayey soil is about $45-60 \%$ with smaller pores. The porosity of loam is about 55-65\% with almost equal proportions of large and small pores. Bulk density and porosity are closely and inversely related to each other (Fig. 3), such that the lower the bulk density, the greater the porosity.

The average soil bulk density in the enclosed area (Fig. 3) was $1.45 \mathrm{~g} / \mathrm{cm}^{3}$ and the average soil porosity was $45.28 \%$. The soil was compact from the aspect of soil compactness (Tab. 1). The maximum soil bulk density was $1.57 \mathrm{~g} / \mathrm{cm}^{3}$ with a corresponding compactness of "very compact". The minimum soil bulk density was $1.15 \mathrm{~g} / \mathrm{cm}^{3}$, with a corresponding compactness of "suitable" (Tab. 1). The soil bulk density in the enclosed area increased from north to south as a whole. The soil bulk density in the down slope was bigger than that in the up slope in the same slope direction. The soil compactness was greater when the sample position is more to the south. It showed that the soil structure, permeability, water permeability and water-holding capacity in the south of the enclosed area were poor and the fertility was low. The difference between soil bulk density and soil porosity in the south and north of the enclosed area was mainly related to the surface vegetation status of the grassland, the ability of the root layer to hold water and the humus on the surface layer. The vegetation was basically low shrubs and herbs in the sample area. 


\section{Distribution characteristics of soil bulk density and soil porosity in the area of cultivated land.}

The bulk density in tilled soil (Fig. 3) was $1.46 \mathrm{~g} / \mathrm{cm}^{3}$ on average. The soil porosity was $44.79 \%$ on average. The soil was "compact" from the soil compactness table (Tab. 1 ). The maximum soil bulk density was $1.5 \mathrm{~g} / \mathrm{cm}^{3}$, and the minimum value of soil bulk density was $1.43 \mathrm{~g} / \mathrm{cm}^{3}$, which indicates it to be very compact, reflecting the farming methods in this area. The soil bulk density in the no tillage area was lower than that in the tillage area. The difference of soil bulk density and soil porosity between north and south was not obvious (Fig. 3), making it difficult to draw any general conclusions. It suggests that the distribution of soil bulk density and soil porosity was uniform in farming area. The reason may be that soil texture in the farmland was relatively uniform, which results in little change of the soil bulk density and soil porosity.

Comparison of the characteristics of soil physical properties in the enclosed area and cultivated area

(1) The soil moisture content in the enclosed area increased by $0.6 \%$ compared with that in the cultivated area. The rainfall runoff and the surface evaporation decreased due to the good surface vegetation cover in the enclosed area, in constrast to the cultivated area where the surface coverage was low and the surface evaporation was high. In addition, the roots of grass species were relatively deep in the enclosed area, which mainly absorb the lower water resulting in high soil moisture in the upper layers of the soil profile. This conclusion is consistent with the results of research by Wang Zhiqiang on the typical vegetation of Pinus tabulaeformis plantations, natural shrubs, abandoned grassland and farmland in the northwest of Shanxi province in semi-arid loess hilly region, which indicated that the soil moisture is reduced due to the low vegetation coverage in farmland, and concentration of rainfall, low precipitation and severe drought resulted in a large amount of surface water evaporation (Wang Zhi-qiang et al., 2002).

(2) The soil bulk density in cultivated land increased by $0.01 \mathrm{~g} / \mathrm{cm}^{3}$ compared to that in enclosed areas, and the soil porosity increased by $1 \%$ due to shallow and numerous fibrous root of herbaceous plants in the enclosed areas. Grass roots increased soil porosity and decreased soil bulk density. In addition, the litter of herbaceous plants on the soil surface was easy to decompose to form soil organic matter, which also reduces the soil bulk density. The increase of soil nutrients in the enclosed areas was good for the survival of a variety of microorganisms and soil animals, promoting their activities, increasing the soil porosity, and indirectly reducing the soil bulk density. Finally, the soil bulk density was relatively high in the cultivated land due to the impact of human activities, which led to soil compaction and reduced soil porosity.

In short, the variance of soil moisture content, soil bulk density and soil porosity in the enclosed area and cultivated area is mainly due to the intense influence of human activities (e.g. tillage, fertilization, mulching, Platycodon grandiflorum cover etc.), ecological and hydrological processes (soil dry wet alternate, surface crust, expansion, and shrinking, etc.) and plant characteristics (e.g. root distribution and canopy effect, rhizosphere microbial activity etc.) in the surface soil. 


\section{CONCLUSIONS}

The variation of soil moisture content, soil bulk density and soil porosity was not significant in the enclosed area and cultivated area. The reason may be the close distance of the two study regions, and the small size of the selected sample areas. Climatic factors like windy days are also likely to be important to consider: there were windier days in the loess hilly area than is the case in other studies, and the soil sampled in this study was primarily top-soil, which is sensitive to wind-related effects and other natural external factors. This means that changes in the physical properties of soil as a result of enclosure were not that obvious. In future studies, it would be useful to expand the sampling area, try to collect deeper soil, and avoid the effect of other factors on the surface soil properties.

None the less, there are some general indications from this study that can provide reference for future research work. Loess soils in the Loess hill region are poor with low nutrient availability. Soil properties were changed in the cultivated region due to human activities. The status of soil moisture, soil porosity and soil solid particles in grassland (enclosed) areas was different with that in cultivated areas. Notably, mulching can improve soil water holding capacity, increase soil fertility, and improve soil development. The enclosure of farmland areas has effects on water, fertility, atmosphere and heat conditions of soil and agricultural production. The implementation of the project of returning farmland to forest and grassland will alleviate soil erosion in the loess hill region, and help improve the ecological environment. This study will provide a scientific reference for theoretical research of the ecological environment. 


\section{ACKNOWLEDGEMENTS}

This study was sponsored by the sub-project of National Key Research and Development Program of China - Desertification Land Management and Sand Industry Technology Research and Development and Demonstration in Inner Mongolia Desertification Area, named Key Techniques and Demonstration of Sand Damage Control in Oasis and Saline-alkali Lake (2016YFC0501003) and supported by a grant of university level project Characteristics of Soil Organic Carbon Source and Sink of Grassland in Inner Mongolia Plateau (YJRC12017). 


\section{REFERENCES}

1. Bojie F., Jun W. and Kerning M., 1999 - Effect of land use on soil water in loess hill area, China Science Foundation, 4, 225-227.

2. Dam R. F., Mehdi B. B., Burgess M. S. E., Madramootoo C. A., Mehuys G. R. and Callum I. R., 2005 - Soil bulk density and crop yield under eleven consecutive years of corn with different tillage and residue practices in a sandy loam soil in central Canada, Soil and Tillage Research, 84, 41-53.

3. Feng M. A., Li X., Zhang J. and Li A., 2005 - Spatial Heterogeneity of Soil Physical Properties in Shapotou Artificial Sand fixing Vegetation Area, Journal of Desert Research, 25, 2, 207-214.

4. Hernanz J. L., Peixoto H., Cerisola C. and Sánchez-Girón V., 2000 - An empirical model to predict soil bulk density profiles in field conditions using penetration resistance, moisture content and soil depth, Journal of Terra mechanics, 37, 167-184.

5. Huang Changyong, 2000 - Soil Science, Beijing: China Agriculture Press, 67-68.

6. Liu H. L., Zhu J. Z., Jin G. L., Fan Y. M. and Wang C. H., 2009 - Characteristic analysis of Seriphidium transillense (Pol jak.) Poljak desert grasslands at different degraded stages in the northern Tianshan Mountains, Acta Agrestia Sinica, 17, 4, 419-427.

7. Ma X., Jiao J. Y., Wen Z. M., Bai W. J. and Jiao F., 2005 - The Changes of Physical Properties in Abandoned Lands During Vegetation Restoration in Hilly and Gully Regions on the Loess Plateau, Research of Soil and Water Conservation, 12, 1, 17-21.

8. Man X. Yu F., Dai W. and Cai T., 1997 - Effect of forest harvesting and afforestation on physical property of soil water, Journal of Northeast Forestry University, 25, 5, 57-60.

9. Qiu B., 2015 - Analysis on soil bulk density of different site types in the semi-arid of Lasa, Hubei Forestry Science and Technology, 44, 6, 24-27.

10. Ruilian H. and Qingchun H., 2003 - Soil Water Changing of Artificial Robinia persudoscacia at Different Site Conditions in Yan an Experimental Area, Journal of North west Forestry University, 18, 174-176.

11. Walker B. H., 1993 - Rangeland ecology: understanding and managing change, Ambio, 22, 2-3, 80-87.

12. Wang Q., 1996 - A Sampling Method in Measuring Forest Soil Bulk Density, Chinese Journal of Ecology, 15, 3, 68-69.

13. Wang Z. Q., Liu B. Y., Hai C. X., Fu J. S., 2002 -Analysis of Soil Water Content of Different Vegetation Types in the North-Western Part of Shanxi Province, Journal of Arid Land Resources and Environment, 16, 4, 53-58.

14. Wilson D. J., Western A. W. and Grayson R. B., 2005 - A terrain and data based method for generating the spatial distribution of soil moisture, Advances in Water Resources, 28, 1, 43-54.

15. Wu H., Chen X., Ye M., Wu H., Shi H. and Shi E., 2005 - Moisture Characteristics and Their Effect Factors of Main Paddy Soils in Tai Lake Region, Journal of Soil and Water Conservation, 19, 1, 181-187.

16. Xing J., Guo J.-Y., Zhao X.-H., Lan D.-M., 2010 - Research on soil physical properties after conversion of cropland to forest in loess hilly region - Taking example of Wuqi County, Journal of Inner Mongolia Agricultural University, 31, 1, 41-46.

17. Yan Q., 2014 - Effect of Rainstorm Patterns and Soil Erosion Control Practices on Soil and Water Loss in Small Watershed on Loess Plateau, Chinese Journal of Agricultural Machinery, 45, 2, 169-175.

18. Yang L., Wei W., Chen L. and Jia F. and Mo B., 2012 - Spatial variability of soil moisture at a regional scale in Loess Plateau, Advances in Water Science, 23, 3, 310-316.

19. Yuan B., 2006 - Research in vegetation restoration and soil remediation of Grain for Green Take Qingyang of Gansu Province as an example.

20. Zhao J.-M., Gao C. and Zhang D.-G., 2010 - Study on the Soil Organic Carbon Density of Alpine Meadow with Different Degradation Degrees in Eastern Qilian Mountains, Acta Agrestia Sinica, 18, 1, 21-25. 
21. Zheng H., Ouvang Z., Wang X., Miao H., Zhao T. and Peng T., 2004 - Effects of forest restoration types on soil quality in red eroded region, Southern China, Acta Ecologica Sinica, 24, 9, 1994-2002.

21. Zhou H., Zhao X., Zhou L., Liu W., Li Y. and Tang Y., 2005 - A study on correlations between vegetation degradation and soil degradation in the "Alpine Meadow" of the Qinghai Tibetan Plateau, Acta Prataculturae Sinica, 14, 3, 31-40. 